\title{
Analisis Retorika Pada Pidato Presiden Jokowi “Bersatu Menghadapi Corona" Sebagai Himbauan Melalui Media Youtube
}

\author{
Faza Fat han Fadhilah ${ }^{1} \&$ Irwansyah $^{1}$ \\ ${ }^{1}$ Department of Communication Science, University of Indonesia \\ Jl. Margonda Raya , Pondok Cina, Kecamatan Beji, Kota Depok, Jawa Barat \\ E-mail: ${ }^{1}$ faza.fathan01@ui.ac.id, ${ }^{2}$ irwansyah06@ui.ac.id
}

Received: June 2021; Accepted: February 2021; Published: December 2021

\begin{abstract}
During this COVID-19 pandemic, many people were confused about how to deal with COVID-19. In dealing with this, President Joko Widodo made a virtual speech to deal with this pandemic in order to prevent the spread of the COVID-19 virus. Based on this background, this study will discuss the meaning of the rhetorical study from President Jokowi, which contains an appeal to continue to live the days according to the Covid 19 protocol. This research was conducted with a qualitative approach and used descriptive analysis methods, which provide an overview and understanding to the reader about Aristotle's rhetorical theory in the art of persuasion carried out by President Jokowi through a press release on "Together Against Corona." with literature studies that already exist in previous research. The formulation of the problem that the researcher raises is how the analysis of the content of President Jokowi's speech "United Facing Corona" delivered through a youtube video intersects with ethos, logos, pathos as dimensions of rhetoric or its aspects. This research shows that President Jokowi, who acts as a communicator in this speech in persuading the public, has fulfilled ethos, logos, and pathos when viewed from Aristotle's art of persuasion. The speech "United Facing Corona" applies the use of five aspects in rhetoric, such as the discovery aspect, the regulatory aspect, the style aspect, the delivery aspect, the memory aspect, and others. The speech "United Facing Corona" as a whole has shown the rhetorical concept of Aristotle.
\end{abstract}

Keywords: Rhetoric; Jokowi's speech; New Media; Ethos; Pathos; Logos.

\begin{abstract}
Abstrak
Di masa pandemi covid-19 ini banyak dari masyrakat yang mengalami kebingungan dalam menghadapi covid-19. Presiden Joko Widodo dalam menghadapi hal tersebut melakukan pidato yang dilakukan secara virtual untuk menghadapi pandemi ini dalam rangka pencegahan penyebaran virus covid-19. Berdasarkan latar belakang tersebut, penelitian ini akan membahas mengenai makna kajian retorika dari presiden Jokowi yang berisikan himbauan untuk tetap menjalani hari-hari sesuai dengan protokol Covid 19. Penelitian ini dilakukan dengan pendekatan kualitatif dan menggunakan metode deskriptif analisis, yaitu memberikan gambaran dan pemahaman kepada pembaca tentang teori retorika Aristoteles dalam seni persuasi yang dilakukan oleh Presiden Jokowi melalui siaran pers tentang "Bersama Melawan Corona". dengan studi pustaka yang sudah ada pada penelitian sebelumnya. Rumusan masalah yang peneliti angkat adalah bagaimana analisis isi pidato Presiden Jokowi "Bersatu Menghadapi Corona" yang disampaikan melalui video youtube bersinggungan dengan ethos, logos, pathos sebagai dimensi dari retorika ataupun aspeknya. Hasil dari penelitian ini ialah Presiden Jokowi yang berperan sebagai komunikator di dalam pidato ini dalam mempersuasi masyarakat telah memenuhi ethos, logos dan pathos jika dilihat dari seni persuasi Aristoteles. Di dalam pidato "Bersatu Menghadapi Corona" menerapkan penggunaan lima aspek yang ada di dalam retorika, seperti adanya aspek penemuan, aspek pengaturan, aspek gaya, aspek penyampaian dan aspek memori dan lainnyaa. Pidato "Bersatu Menghadapi Corona" secara keseluruhan sudah menunjukkan konsep retorika dari Aristoteles.
\end{abstract}

Keywords: Retorika; Pidato Jokowi; New Media; Ethos; Pathos; Logos. 


\section{PENDAHULUAN}

Istilah dari "media baru" sudah digunakan sejak tahun 1960-an dan istilah tersebut harus dapat mencakup serangkaian teknologi komunikasi terapan yang beragam dan berkembang (McQuail, 2010). Menurut Enzensberger (Dalam McQuail, 2010) Teknologi yang dibawa oleh media baru dapat mengembangkan aktivitas komunikasi massa. kebangkitan media baru dipandang oleh sebagian orang sebagai pemberontakan melawan komunikasi massa, sebuah gagasan yang memiliki sejarah panjang dalam teori kritis. Dua kekuatan pendorong utama perubahan pada awalnya adalah komunikasi satelit dan pemanfaatan komputer. Kunci kekuatan besar komputer sebagai mesin komunikasi terletak pada proses digitalisasi yang memungkinkan semua jenis informasi dalam semua format dilakukan dengan efisiensi yang sama. Perkembangan teknologi dengan proses digitalisasi ini dapat mengubah beberapa aspek pada komunikasi massa.

Dengan berkembangnya teknologi dan digitalisasi pada arus komunikasi massa, saat ini proses komunikasi massa menjadi lebih tersebar dan efisien. Kini, platform yang digunakan sebagai wadah untuk melakukan proses komunikasi massa tidak hanya terlepas pada televisi, koran dan media lama lainnya, tapi sudah merambah ke media daring lain seperti aplikasi. Salah satunya adalah Youtube. Menurut (Vytiaz, 2018), youtube merupakan sebuah platform berbasis digital yang dapat menggantikan televisi, walaupun youtube tidak mewakili tv nasional tapi popularitas dari televisi yang setiap tahunnya terus menurun, hal ini disebabkan karena Youtube memulai perubahan dalam dunia hiburan dan cara penyiaran. Berdasarkan analitik dari youtube.com, pengguna youtube pada saat ini sudah mencapai 2 miliar pengguna yang login ke dalam youtube. Hal ini menjadikan bahwa youtube pantas untuk dijadikan sebagai platform komunikasi massa.

Pada tanggal 18 April 2020, Joko Widodo sebagai Presiden Indonesia melakukan siaran pers perihal bagaimana kita menyikapi corona yang melanda Indonesia pada saat ini. Presiden Jokowi melakukan pidato dengan tujuan untuk menyampaikan kepada masyarakat Indonesia agar tetap mencegah penyebaran virus corona. Siaran pers presiden Jokowi ini diliput salah satunya oleh CNN Indonesia di akun youtubenya. Jokowi sebagai kepala negara memiliki kewajiban agar penyebaran virus corona di Indonesia ini semakin menurun, oleh karenanya Presiden Jokowi melakukan pidato yang bertujuan untuk mengajak masyarakat Indonesia agar terus bersikap disiplin diri bersama-sama agar covid-19 semakin menurun. Jokowi juga menyampaikan agar kita semua sebagai masyarakat Indonesia agar terus saling peduli, gotong royong, dan saling membantu dalam menghadapi pandemi yang sedang terjadi saat ini.

Isi dari pidato Jokowi yang bertemakan "Bersatu Menghadapi Virus Corona" ini bersifat persuasif. Presiden Jokowi mengajak dan menghimbau agar masyarakat tetap disiplin dan juga menghimbau para kepala daerah untuk melakukan penanganan dan memperbanyak test covid-19 untuk masyarakat. Presiden Jokowi sebagai public speaker sebelum melakukan pidato harus memahami seni dari persuasif. Aristoteles mengatakan bahwa ada 3 unsur di dalam beretorika, yaitu logos, pathos, dan ethos. Logos adalah bentuk logika dan argumen yang digunakan oleh pembicara yang bersifat rasional untuk diberikan kepada pendengar, kemudian pathos yang merupakan bentuk emosi atau perasaan yang dapat menggerakan perasaan audiens dan yang terakhir adalah ethos yang merupakan kredibilitas pembicara (Griffin, 2009). Marta (2014) menjelaskan bahwa logika atau logos diturunkan dari alur 
argumen dalam percakapan yang didasarkan pada kebenaran apa adanya. Sedangkan etos atau etika merupakan pembuktian dari etika dimana karakter penutur diwujudkan melalui pesan sehingga timbul kepercayaan diri penutur. Kemudian, kesedihan atau emosi dapat dilihat dari beberapa fakta yang disebutkan oleh pembicara menjadi argumen. Penelitian ini akan membahas sikap persuasi dari pidato Jokowi "Bersatu Menghadapi Virus Corona" di youtube. Sehingga jika seorang pembicara ingin mempengaruhi atau mempersuasi pendengar dapat mengetahui cara beretorika di dalam seni persuasi atau retorika Aristoteles.

Jika dikaitkan dengan penelitian sebelumnya mengenai pidato Presiden Jokowi dalam tema edukasi, struktur retorika yang muncul pada pidato seperti ini harusnya dapat dikaitkan dengan temuan seperti, pengenalan yang dilakukan, isi ujaran dan kesimpulan yang diperlihatkan. Namun pada pembahasannya, peneliti masih belum menjelaskan bagaimana ethos, pathos, logos berkaitan dengan makna retorika secara mendetail (Noermanzah: 2019). Pada penelitian lain tentang pidato Presiden yang menafsirkan tuturan lisan dari perspektif hukum retorika dijelaskan bagaimana kajian retorika dalam pidato presiden Indonesia dilihat dari lima prinsip seperti penemuan, penataan, gaya, penyampaian, dan ingatan. Dikatakan secara hasil, bahwa pidato presiden telah memenuhi lima kriteria retorika (Satria \& Adek: 2019).

Lainnya, retorika juga bisa dikaitkan dengan ilmu politik dengan melihat unsur pathos didalamnya, dalam penelitiannya ditemukan hasil jika phatos bisa menjadi strategi retorika yang utama untuk membujuk khalayak (Sanjaya., et al: 2017). Ada pula proses menghubungkan retorika dengan proses belajar yang dilakukan dosen kepada mahasiswa selama masa pandemi, ditemukan jika ethos, pathos, dan logos bisa menambah kualitas komunikasi jika menggunakan instruksi yang tepat bahkan melalui media daring sekalipun (Nuryadin \& Pamungkas: 2019). Dari masing-masing penelitian tersebut masing-masing sudah mengaitkan retorika namun belum dalam keseluruhan ataupun membahas pidato jokowi pada tema ini secara khusus, sehingga pada penelitian ini kami akan membahas mengenai bagaimana kajian retorika pidato Jokowi dalam menghadapi Corona yang disampaikan melalui platrform Youtube jika dibedah berdasarkan perspektif teori komunikasi.

\section{TINJAUAN LITERATUR}

\section{Covid 19}

Pada awal tahun 2020, Indonesia digemparkan dengan masuknya virus yang menggegerkan seluruh dunia. Diketahui virus ini sudah mulai merajalela dan muncul di khalayak sejak akhir tahun 2019. Banyak pro, kontra, serta issue muncul di permukaan saat kedatangannya, seperti diawali oleh gejala umum yang hanya terkena flu hingga menyebabkan kematian. Ini semua diawali oleh berita media yang muncul dengan berbagai headline dan membuat perspektif baru dalam masyarakat. Saat awal hadirnya virus ini banyak masyarakat yang menunjukkan ketidak percayaannya karena merasa virus ini hanya menjadi "alat" untuk menakuti masyarakat. Namun setelah pemerintah menyatakan keadaan darurat dan mulai melakukan PSBB pada masing-masing wilayah barulah masyarakat percaya lalu menjaga diri sendiri untuk tetap terhindar dari virus tersebut. 
PSBB adalah pembatasan sosial berskala besar untuk mempercepat penanganan covid 19. Hal ini menjadi tanggung pemerintah daerah dan pusat sebagai bentuk untuk melindungi masyarakat agar virus ataupun wabah ini dapat segera diatasi. PSBB sendiri merupakan pembatasan kegiatan dalam suatu wilayah yang diduga terinfeksi covid-19. Ini semua dilakukan agar penyebaran covid-19 menjadi terbatas. Pembatasan ini kemudian berdampak pada sekolah, tempat kerja, perbelanjaan, keagamaan, hingga acara pernikahan. Selain harus menggunakan masker dan menyiapkan hand sanitizer kemanapun masyarakat pergi, ternyata pembatasan jam aktivitas juga dicanangkan pemerintah untuk melindungi khalayak. Akhirnya semua kegiatan yang biasanya dilakukan secara fisik, beralih ke penggunaan daring (Kominfo.go.id:2020).

Sistem daring ini cukup membantu komunikasi dalam masyarakat karena adanya pembatasan. Masyarakat jadi lebih memanfaatkan kegiatan, keagamaan, pertemuan hingga bisnis mereka untuk dialihkan ke ranah platform online seperti, zoom bahkan Youtube. Pemerintah juga menjadikan media daring untuk terus berkampanye kepada masyarakat tentang apa yang harus disikapi oleh masyarakat Indonesia. Contohnya seperti Pidato Jokowi yang berisi himbauan kepada masyarakat agar dapat bekerja sama dalam menghadapi corona dengan memperhatikan diri sendiri juga sekitar.

\section{New Media}

New Media diprakarsai oleh Marshal McLuhan selaku akademisi yang memperkenalkan media sebagai perkembangan teknologi komunikasi. Meski saat ini istilahnya menjadi tidak sama. new media diartikan sebagai teknologi komunikasi baru sebagai efek untuk menghasilkan budaya yang lebih luas untuk mempengaruhi dinamika kehidupan manusia. Jadi bentuk dari new media itu sendiri selalu berkembang dari masa ke masa sesuai perkembangan zaman. Ronal Rice menambahkan, new media merupakan teknologi komunikasi yang memungkinkan penggunanya untuk melakukan pertukaran aktivitas melalui sarana yang ada. Maksudnya, khalayak dapat membuat bahkan menyebarluaskan suatu konten secara daring atau online seperti menyebarkan foto, video, bahkan suara (Davey: 2010).

Pada zaman ini new media sendiri berevolusi menjadi sesuatu yang lebih terdigitalisasi sehingga dapat memungkinan para penggunanya untuk bisa menelusuri berbagai konten media dimanapun dan kapanpun. New media bersifat bebas dan dapat langsung dikonsumsi oleh siapa saja. Bahkan, dalam pengaplikasiannya masyarakat juga ikut berkontribusi menyebarkan penggunaan ke khalayak lainnya sehingga apa yang diprakarsai oleh masing-masing bentuk media dapat digapai oleh banyak pihak. Salah satu new media masa kini yang akan dibahas oleh peneliti adalah Youtube sebagai media pidato oleh Presiden Jokowi.

Youtube merupakan sebuah platform digital yang dapat menggantikan televisi dan popularitasnya selalu meningkat setiap tahun. Hal ini karena Youtube memberikan perubahan dalam dunia hiburan dan cara penyiaran. Berdasarkan analitik dari youtube.com, pengguna youtube pada saat ini sudah mencapai 2 miliar pengguna. Sehingga ni menjadikan youtube pantas dijadikan sebagai platform komunikasi massa. (Vytiaz, 2018). 


\section{Retorika Ethos, Logos, dan Pathos}

Menurut Aristoteles, di dalam seni retorika dalam mempersuasi dapat dilakukan dengan cara artistic ataupun inartistic. Inartistic adalah cara mempersuasi yang tidak dibuat oleh pembicara atau berasal dari bukti yang sebenarnya sedangkan cara artistic adalah cara persuasi yang dibuat oleh pembicara atau bukti yang berasal dari pembicara. Di dalam cara artistic terdapat 3 hal yang menjadi kunci didalam retorika artistic. Yaitu logos, ethos, dan pathos. Logos adalah bentuk logika dan argumen yang digunakan oleh pembicara yang bersifat rasional untuk diberikan kepada pendengar, kemudian pathos yang merupakan bentuk emosi atau perasaan yang dapat menggerakan perasaan audiens dan yang terakhir adalah ethos yang merupakan kredibilitas pembicara (Griffin, 2009).

Aristoteles dalam hal retorika lebih memfokuskan retorika sebagai orator yang dapat mengimplementasikan alat persuasi berupa ethos, logos, dan pathos ketika melakukan pidato (noermanzah, et.al, 2019). Zhu (2005) ethos yang merupakan bagian dari seni retorika yang terkait dengan kredibilitas dari pembicara, pembicara harus bisa menciptakan kredibilitasnya tersendiri dan menjaga hubungan moral antara dirinya dengan isi dari pidato tersebut. Ethos merupakan bentuk tanggung jawab atas empati pertama di antara publik dengan pembicara, ethos mengacu kepada bagaimana pendengar atau publik memandang karakter dari pembicara berdasarkan pesan dan cara penyampaiannya. Nilai integritas hanyalah sebagian dari keseluruhan penilaian yang akan dilihat oleh publik (Griffin, 2009).

Menurut Demirdöğen (2010), logos adalah sesuatu yang dapat membuat logika menjadi tertarik sehingga dengan menggunakan logos, persuasi dapat dilakukan dengan memberikan bukti-bukti ataupun bukti yang nyata. Dalam analisis retoris, daya tarik logo dapat diidentifikasi dari penggunaan argumentasi, logika, justifikasi, klaim, data, dan bukti (Al-Momani, 2014). Aristoteles mengaitkan logos sebagai isi atau konten rasional pidato. Logos juga dapat diartikan sebagai pembelaan rasional yang terkait dengan argumen yang bersifat verbal. Dan di dalam bagian pidato, unsur dari logos ini bertujuan untuk membuktikan sesuatu (Ebel, 2012).Logos juga merupakan elemen persuasi, yang ditemukan atau dikerjakan, dengan sarana artistik untuk mempengaruhi audiens, persuasi yang diberikan berdasarkan dengan kebenaran yang nyata. (Sloane, 2001).

Pathos merupakan alat persuasi yang memanfaatkan penggunaan emosi atau perasan untuk membujuk yang bertujuan untuk menciptakan rasa simpati kepada pembicara. Secara singkat, Aristoteles menganggap bahwa pathos merupakan perasaan keinginan untuk bertindak yang diwujudkan secara fisik dan impulsif (Gross \& Walzer, 2008). Dengan menggunakan pathos ketika berpidato dapat menambah rasa simpatisan dari publik terhadap pembicara, baik secara penampilan pembicara maupun dari perkataan yang dibuat oleh pembicara (Noermanzah, 2019). Pathos juga merupakan perasaan dari publik atau audiensnya oleh pembicara, pathos mengacu kepada respon emosional yang positif ataupun sesuatu hal yang menyedihkan yang dicoba untuk ditarik oleh pembicara (Griffin, 2009).

\section{Prinsip retorika}

Dalam mengukur kualitas dari kemampuan pembicara dalam melakukan pidato kepada publik, terdapat 5 standar kualitas yang harus dimiliki oleh pembicara dalam berpidato, yaitu argumen (invention), urutan materi (arrangement), pemilihan bahasa (style), teknik presentasi (delivery), dan ingatan (memory) (Griffin, 2009). 
Menurut Cicero (1949) mengatakan bahwan De Inventione (penemuan) merupakan peran yang penting di dalam beretorika, penemuan mempunyai peran penting untuk membuat isi atau teks yang di klaim secara serius dan memiliki otoritas sebagai sesuatu yang penting untuk mempengaruhi para pendengar. Penemuan merupakan argumen yang valid atau terlihat valid untuk membuat alasan seseorang menjadi hal yang masuk akal (Cicero, 1949). Penemuan (invention) adalah salah satu kemampuan yang harus dimiliki oleh pembicara. Dengan adanya penemuan (invention), pembicara sudah dapat mengetahui apa yang akan dibahas atau sudah mengetahui topik apa yang akan diangkat pada isi dari pidato (Griffin, 2009).

Kemudian aspek yang ketiga yang ada di dalam retorika adalah Gaya bahasa (Style). Aristoteles dalam membahas gaya bahasa ketika retorika berfokus kepada metafora. Metafora dapat membantu audiens untuk memahami apa yang dikatakan oleh pembicara. dengan menggunakan metafora, audiens terbantu untuk memvisualisasikan dan membuat tergerak secara emosional untuk bertindak (Griffin, 2009). Gaya atau cara penyampaian suatu ide dalam pidato akan berbeda-beda tergantung dengan pembicaranya. Seorang pembicara harus memiliki kapasitas dalam menyampaikan menggunakan gayanya sendiri, sehingga dengan cara penyampaian yang dibawa oleh pembicara dapat menarik perhatian audiens dalam upaya untuk membentuk simpati, menyamakan ide dan pandangan serta dapat menangkap pesan apa yang ingin disampaikan melalui pidato tersebut (Satria \& Adek, 2019).

Aspek keempat yaitu pembawaan atau cara penyampaian (Delivery). Aspek penyampaian di dalam konsep retorika Aristoteles adalah sebuah bentuk presentasi yang menarik perhatian sehingga dapat mempersuasi audiens. Menurut Aristoteles, cara menyampaikan pidato yang baik adalah dengan tidak membuat-buat atau direncanakan oleh pembicara, semakin terlihat alamiahnya makan akan semakin dapat mempersuasi audiens (Griffin, 2009). Menurut Burke (2016), penyampaian yang bersifat lisan dengan fokus pada intonasi, durasi, bunyi dan aspek paralinguistik seperti gerakan tubuh, tatapan mata, gerak tubuh dan ekspresi wajah. Di Dalam aspek penyampaian ini merupakan aspek yang berkaitan erat dengan public speaking, karena hal ini dilihat dari bagaimana pembicara dalam mengingat, menyampaikan dan kemudian melakukan pidato di dalam ruang lingkup public (Setiansah et.al, 2019).

Kemudian aspek ingatan (memory) adalah aspek terakhir di dalam retorika. Ingatan merupakan faktor yang harus dimiliki dalam setiap pembicara ketika berpidato, hal ini dilakukan agar para pembicara tidak kehilangan kata-kata ketika sedang berpidato (Griffin, 2009). Selain aspek ingatan sebagai mengingat dari materi yang dibuat, ingatan merupakan salah satu sumber terbaik untuk dijadikan sebagai awal dari pidato dan ingatan yang dimaksud adalah memori publik. Memori publik mewakili pengetahuan sosial, konvensi, opini public, nilai-nilai, dan kejadian atau pengalaman yang dapat diberikan oleh pembicara dalam suatu pidato, dengan menggunakan memori publik dapat meyakini apa yang dikatakan oleh pembicara ketika berpidato dan beresonansi dengan apa yang ada pada isi pidato. Memori public dapat merepresentasikan kenangan yang sudah terjadi dari generasi ke generasi melaluI cerita ataupun frasa yang berupaya melanjutkan dan menjaga kenangan itu di masa sekarang. Kenangan itu akan menjadi aspek yang dapat membuat perasaan dari audiens menjadi tergerak, terlebih jika kenangan tersebut merupakan pengalaman yang 
pernah dirasakan oleh audiens sehingga mampu untuk membuat audien menjadi terpusat perhatiannya kepada pembicara (Farrel, 1999).

\section{METODE PENELITIAN}

Metode yang kami gunakan dalam penelitian ini adalah studi pustaka. Studi pustaka adalah sebuah kajian yang digunakan untuk memperoleh data-data atau teori dari berbagai sumber seperti buku, jurnal ilmiah, artikel, atau sumber-sumber lain yang ada hubungannya dengan masalah yang akan dibahas dalam penelitian ini. Literatur yang digunakan untuk menjawab permasalahan yang akan diangkat oleh penulis dalam hal ini adalah bagaimana teori retorika Aristoteles dapat mengetahui bagaimana konsep retorika Aristoteles dalam mempersuasi masyarakat Indonesia pada pidato Jokowi "Bersama Melawan Corona" dalam siaran pers 18 April 2020. Penelitian ini dilakukan dengan pendekatan kualitatif dan menggunakan metode deskriptif analisis, yaitu memberikan gambaran dan pemahaman kepada pembaca tentang teori retorika Aristoteles dalam seni persuasi yang dilakukan oleh Presiden Jokowi melalui siaran pers tentang "Bersama Melawan Corona". Data yang digunakan oleh penulis dalam penelitian ini adalah data sekunder.

Dalam pengumpulan datanya, pertama, kami mencari literatur yang membahas tentang perkembangan teori retorika aristoteles. Kedua kami mencari literatur yang menghubungkan antara teori retorika Aristoteles dengan pidato kewarganegaraan dan mengunduh video pidato Jokowi dari akun youtube CNN Indonesia sebagai bahan penelitian. ketiga kami mencari literatur terkait sikap persuasi dalam pidato. Kemudian kami mencari literatur tentang seni persuasi yang diterapkan pada pidato yang dilakukan oleh aparatur negara untuk mempersuasi khalayak umum. Terakhir, kami melakukan analisis deskriptif yang menjelaskan hubungan antara seni retorika Aristoteles dalam mempersuasi masyarakat Indonesia pada pidato Jokowi "Bersama Melawan Corona" dalam siaran pers 18 April 2020.

\section{HASIL DAN PEMBAHASAN}

Penelitian ini mengacu kepada pidato Jokowi yang bertemakan "Bersatu Melawan Corona”. Jokowi sebagai kepala negara melakukan pidato untuk mengajak masyarakat Indonesia mencegah penyebaran virus corona yang melanda Indonesia pada saat ini. Jokowi ingin mengajak atau mempersuasi masyarakat Indonesia melalui pidato, Menurut Aristoteles, seni persuasi yang artistic adalah persuasi yang menerapkan ethos, logos, dan pathos ketika melakukan retorika (Griffin, 2009). Jika dilihat dari konsep retorika Aristoteles, 3 konsep kunci dari teori ini telah diterapkan pada pidato yang dilakukan oleh Presiden Jokowi.

Ethos adalah kredibilitas dari pembicara, Jokowi yang merupakan kepala negara Indonesia tentu sudah memiliki kredibilitas untuk melakukan pidato kewarganegaraan terkait dengan virus corona. Presiden Jokowi harus ikut andil dalam proses mencegah penyebaran virus corona. Kredibilitas Presiden Jokowi sudah tidak perlu diragukan lagi Sebagai kepala negara, Jokowi harus menjaga kesejahteraan rakyat terlebih lagi di masa pandemi ini. Di dalam suatu negara, seorang kepala negara harus mampu untuk berkomunikasi kepada masyarakatnya di dalam konteks apapun dengan jelas dan tepat. Oleh karenanya unsur ethos yang merupakan kredibilitas pembicara sudah terpenuhi 
Unsur yang kedua adalah Logos. Menurut Aristoteles Logos adalah bentuk logika dan argumen yang digunakan oleh pembicara yang bersifat rasional untuk diberikan kepada pendengar (Griffin, 2009). Logos sesuatu yang dapat membuat logika menjadi tertarik sehingga dengan menggunakan logos, persuasi dapat dilakukan dengan memberikan bukti ataupun bukti yang nyata (Demirdöğen, 2010). Ketika ingin melakukan retorika kepada publik, seorang pembicara harus dapat membentuk dan menemukan argumen yang bersifat logika untuk disampaikan kepada pendengar. Di dalam pidato Presiden Jokowi, isi dari pidato tersebut berdasarkan dengan fakta dan bukti yang nyata. Jokowi mengangkat argument terkait corona ke dalam isi pidato sehingga, para audiens tertarik untuk mendengarkan pidato dari Jokowi. Berdasarkan hal ini, unsur kedua logos sebagai bukti nyata dan rasional dalam berpidato sudah diterapkan.

Unsur yang terakhir adalah Pathos, alat persuasi yang memanfaatkan penggunaan emosi atau perasan untuk membujuk yang bertujuan untuk menciptakan rasa simpati kepada pembicara. Secara singkat, Aristoteles menganggap bahwa pathos merupakan perasaan keinginan untuk bertindak yang diwujudkan secara fisik dan impulsif (Gross \& Walzer, 2008). Di dalam isi pidatonya, Jokowi banyak menggunakan gaya bahasa yang memotivasi dengan intonasi suara yang tenang dan lugas. Tema yang diangkat "Bersatu Melawan Corona" pun sudah menjadi tema yang menarik rasa simpati dari para audiens untuk bergerak bersama dalam pencegahan virus corona. Dilihat dari hal itu, unsur pathos juga sudah diterapkan di dalam retorika pidato Jokowi.

Seorang komunikator yang ingin menjadi pembicara dalam berpidato harus memahami seni persuasi terlebih dahulu. untuk dapat membuat audiens menjadi terpengaruhi oleh persuasi yang dilakukan oleh pembicara, terdapat beberapa aspek yang harus dipahami sebelum berpidato. Menurut Aristoteles, terdapat 5 aspek yang harus dimiliki oleh pembicara dalam berpidato, yaitu argumen (invention), urutan materi (arrangement), pemilihan bahasa (style), teknik presentasi (delivery), dan ingatan (memory) (Griffin, 2009). penelitian ini mengkaji sikap persuasi pada pidato jokowi yang bertemakan "bersatu Melawan Corona" yang diunggah di youtube melalui kelima aspek tersebut. kajian dari pidato tersebut dilihat dari 5 aspek retorika sebagai berikut:

1. Aspek penemuan merupakan sebuah gagasan atau tema yang diangkat dalam berpidato untuk mempersuasi masyarakat.

Teks pidato Jokowi:

"di dunia saat ini tengah berperang melawan pandemic Corona, saat ini ada 213 negara terpapar mulai dari negara berkembang hingga negara maju berperang melawan pandemic Corona termasuk negara kita Indonesia"

Teks pidato Jokowi:

"saat ini obat ampuh untuk melawan virus Corona belum ada, tapi penyebaran corona dapat dicegah dengan kedisiplinan yang kuat dari kita sendiri”"

Mengutip pidato di atas, adanya unsur di dalam pidato Jokowi untuk mempersuasi masyarakat Indonesia agar penyebaran virus corona dapat dicegah. Perkataan Jokowi “...penyebaran corona dapat dicegah dengan kedisiplinan yang kuat dari kita sendiri” merupakan gagasan yang ingin disampaikan oleh pembicara, yaitu adanya sikap persuasi dari 
Jokowi dalam pidato tersebut yang disampaikan secara langsung kepada masyarakat. Pada kutipan pidato di atas juga merupakan bentuk gagasan awal sebagai bahasan yang akan disampaikan kepada masyarakat.

2. Aspek pengaturan merupakan cara untuk menyusun pidato agar audiens lebih dapat memahami isi dari pidato.

Teks pidato Jokowi:

"saat ini obat ampuh untuk melawan virus Corona belum ada, tapi penyebaran korona dapat dicegah dengan kedisiplinan yang kuat dari kita sendiri. Iya, disiplin diri mulai dari disiplin menggunakan masker, disiplin menjaga jarak, disiplin hindari kerumunan.. dan ini harus dilakukan secara bersama-sama dan terus-menerus tidak boleh terputus."

Kutipan pidato di atas merupakan bagian awal dari pidato yang dilakukan oleh Jokowi. Jokowi melakukan organisasi pesan yang ada di dalam pidato tersebut yang kemudian disampaikan kepada public dengan bertahap dan runut. Dengan melakukan organisir pesan dan menyampaikannya secara runtut maka pembicara secara bertahap dapat menggiring opini kepada pendengar dalam melihat masalah yang diangkat dalam pidato.

3. Aspek Gaya merupakan cara menyampaikan pidato kepada public untuk menarik perhatian dari pendengar

Teks pidato Jokowi:

"Serta adanya berbagai uluran tangan untuk bantuan kemanusiaan cerita Seorang warga yang bergejala covid didalam suatu lingkungan dan tetangganya saling membantu dan tidak mengucilkannya adalah contoh yang harus ditiru."

Teks pidato Jokowi:

"gerakan-gerakan saling bantu tersebut harus diangkat dimunculkan ke permukaan bukan untuk disombongkan tapi untuk menjaga harapan, dijadikan sebagai inspirasi dan akan bermanfaat jika dapat ditiru ulang, oleh yang lain secara masif."

Dari gaya bahasa dalam menyampaikan pesan pada pidato tersebut, Jokowi menggambarkan keadaan sekarang yang sulit akan tetapi masih ada aksi kemanusian dan uluran tangan untuk membantu sesamanya. Dalam gaya bahasanya, Jokowi memakai unsur pathos yang kuat untuk menarik perasaan dari pendengarnya. Sehingga para pendengar dari pidato Jokowi bereaksi dengan ucapan dari Jokowi.

4. Aspek penyampaian merupakan cara berpidato kepada publik untuk mempersuasi pendengarnya

Menurut Burke (2016), penyampaian yang bersifat lisan dengan fokus pada intonasi, durasi, bunyi dan aspek paralinguistik seperti gerakan tubuh, tatapan mata, gerak tubuh dan ekspresi wajah. Di Dalam aspek penyampaian ini merupakan aspek yang berkaitan erat dengan public speaking. Ketika Presiden Jokowi melakukan pidato dengan tema "Bersatu 
Menghadapi Virus Corona" intonasi yang digunakan oleh Jokowi tetap terlihat tenang dan membangun. Walaupun dari gerakan ataupun gesture tubuh dari Jokowi terlihat pasif dan tidak banyak gerak, tetapi hal ini sesuai dengan gaya penyampaian Jokowi yang berkesan tenang dan tegas.

5. Aspek memori atau ingatan merupakan bentuk argumentasi yang dapat memusatkan perhatian kepada pembicara

Teks pidato Jokowi:

"di dunia saat ini tengah berperang melawan pandemic Corona, saat ini ada 213 negara terpapar mulai dari negara berkembang hingga negara maju berperang melawan pandemic Corona termasuk negara kita Indonesia"

Didalam pidatonya, Jokowi tidak memakai aspek ingatan atau memori yang mengarah kepada suatu kejadian yang pernah terjadi pada masa lalu. Akan tetapi Jokowi menggunakan aspek ingatan dengan menceritakan kejadian atau pengalaman yang sedang masyarakat Indonesia rasakan. Pada bagian "di dunia saat ini tengah berperang melawan pandemic Corona, saat ini ada 213 negara terpapar..." adalah kejadian yang pada saat ini masyarakat Indonesia sedang rasakan. Sehingga pendengar mengalami pengalaman yang sama dengan apa yang dikatakan oleh pembicara. bentuk pengalaman atau kenangan yang sama dapat membuat pendengar menjadi lebih bereaksi kepada pembicara dan memfokuskan perhatiannya kepada pembicara (Farrel, 1999).

Jika dikaitkan dengan pemaparan-pemaparan diatas dapat dilihat jika pidato Jokowi yang berjudul "Bersatu Melawan Corona" telah memenuhi dimensi yang seharusnya ada pada Retorika. Mulai dari ethos, kita tahu Jokowi merupakan orang nomor 1 di Indonesia karena merupakan kepala negara. Statusnya sebagai kepala keluarga membuat beliau sangat memenuhi klasifikasi ethos yang berkaitan dengan kredibilitas, terutama kredibilitas penyampaian pidato sebagai himbauan bagi masyarakat apapun medianya. Lalu, keanekaragaman masyarakat di Indonesia membuat perspektif individu satu dengan yang lainnya muncul secara berbeda. Persamaan persepsi merupakan hal yang wajib menjadi tujuan dalam pidato Jokowi karena nilai logos menjadi faktor untuk menentukan apakah pidatonya sudah rasional dan diterima berbagai khalayak. Dari analisisnya yang dilakukan peneliti diatas terlihat bagaimana komponen ataupun isi dalam pidato Jokowi mampu memperlihatkan logos secara nyata. Ketiga adalah Pathos, media persuasif yang digunakan jokowi untuk menyampaikan pesannya adalah Youtube. Seperti yang kita ketahui persuasif sifatnya adalah membujuk atau mengajak orang lain dengan penggunaan emosi. Dalam keadaan negara yang masih dipenuhi ketakutan akan merebaknya virus covid-19, Presiden Jokowi berhasil mengajak masyarakat dengan edukasi yang ia berikan melalui video berbasis online tersebut dengan baik.

Selain ethos, pathos, dan logos, tentu kita tidak boleh lupa pada pidato ini juga ditemukan bagaimana isinya sudah memiliki 5 aspek lain dalam retorika. Pertama, dari aspek penemuan yang menjadi gagasan atau tema pernyataan Jokowi yang "“....penyebaran corona dapat dicegah dengan kedisiplinan yang kuat dari kita sendiri" telah menunjukkan gagasan awal untuk disampaikan ke masyarakat. Kedua, dari aspek pengaturan untuk penyusunan pidato, Jokowi mampu menyampaikan secara runut sehingga pendengar akan langsung 
melihat masalah yang diangkat. Ketiga, dari aspek gaya, sambil menggambarkan aksi kemanusiaan, Jokowi mampu membuat pendengar bereaksi saat beliau menghubungkan unsur pathos di dalamnya. Keempat adalah aspek penyampain, tentu sudah tidak asing lagi intonasi yang dilakukan oleh presiden Jokowi dan pembawaanya membuat ia menjadi terlihat dan tenang untuk menyampaikan himbauan kepada para masyarakatnya. Terakhir, dnegan menggunakan aspek ingatan yang dialami masyarakat Indonesia pada saat ini mampu membuat pendengar seperti memiliki pengalaman yang sama dan fokus kepada pembicara.

\section{KESIMPULAN}

Dari penelitian diatas, konsep retorika Aristoteles dalam seni persuasi masih relevan untuk digunakan dalam membahas cara mempersuasi melalui berpidato. Teori retorika Aristoteles walaupun merupakan teori yang sudah berumur panjang, akan tetapi teori ini masih menjadi acuan dalam seni berpidato untuk mempersuasi khalayak umum. Konsep logos, pathos, dan ethos masih menjadi kunci dalam seni retorika. Kelima aspek yang ada di dalam retorika yaitu penemuan, pengaturan, gaya, penyampaian, dan ingatan masih menjadi aspek yang dapat mempengaruhi audiens jika diterapkan ketika melakukan pidato. Di dalam pidato Jokowi yang bertemakan "Bersatu Melawan Corona" menerapkan secara keseluruhan konsep dari retorika Aristoteles. Jokowi sebagai presiden yang memiliki kredibilitas dan pengaruh kepada masyarakat Indonesia berpidato untuk bersama-sama berusaha untuk mencegah penyebaran covid-19 dengan menggunakan bahasa yang membuat perasaan seseorang menjadi tergerak sudah memenuhi konsep ethos, logos, dan pathos. Ketika Jokowi melakukan pidato kelima aspek dari retorika pun diterapkan oleh Jokowi, mulai dengan menemukan bukti sebagai gagasan dari pidato kemudian menyampaikan isi dari pidato secara bertahap dan runut dengan pembawaan pidato yang khas oleh Jokowi sampai dengan pernilihan gaya bahasa ketika berpidato sudah memenuhi kelima aspek dari retorika.

\section{DAFTAR PUSTAKA}

Burke, Michael. 2016. "Discourse Implicature, Quintilian and The Lucidity Principle: Rhetorical Phemomena in Pragmatics”. 2016. Vol 17. No 1.

Davey, Chris J., et al (2010). New Media and teh courts: The Current Status and a Look at the Future. Atlanta: CCPIO.

Demirdöğen, Ü. D. (2010). The roots of research in (political) persuasion: Ethos, pathos, logos and the Yale studies of persuasive communications. International Journal of Social Inquiry, Vol 3(1), 189-201.

Griffin, E. (2009). A First Look at Communication Theory. New York: McGraw-Hill.

Gross, A. G., \& Walzer, A. E. (2008). Rereading Aristotle's Rhetoric. Southern Illinois University Press.

Ilham Nuryadin, Riyanda., et al. (2019). Komunikasi Dosen Dalam Era Digital Dengan Pendekatan Arsitotelian Rethorical. Universitas Kebangsaan.

Marta, IN. (2014). Retorika Edisi 2 [Edition Rhetoric]. Yogyakarta: Graha Ilmu. 
McQuail, D. (2010). McQuail's Mass Communication Theory. Netherlands: University of Amsterdam

Noermanzah, et. All. (2019). Joko Widodo's Rhetorical Structure In The Presidential Speeches For Addressing Educational Problems. International Journal Of Scientific \& Technology Research Volume 8(10).

Sanjaya, Andika. et al. (2019). Pemimpin Minoritas dan Strategi Retorika Pathos dalam Kampanye: Analisis Isi Deskriptif Pesan Strategi Retorika dalam Facebook Kampanye Pemilihan Gubernur. Jurnal Komunikasi Indonesia: Jakarta.

Satria, D \& Muhammad, A. (2019). The Study Of Five Rhetoric Principles in Indonesia. International Conference on Language, Literature, Culture, and Education (ICOLLITE 2019). Indonesia

Setiansah, et. All. (2019) Rehtorical Analysis of Joko Widodo and Prabowo Subianto at the 2019 Election Open Debate. International Conference on Language, Literature, Culture, and Education (ICOLLITE 2019). Indonesia

Sloane, T. O. (2001). Encyclopedia of rhetoric. Oxford University Press.

Stephen W. Liitlejohn, Karen A. Foss, 2009, Teori Komunikasi. Salemba Humanika.

Thomas Farrell, "Knowledge, Consensus, and Rhetorical Theory," in Contemporary Rhetorical Theory: A Reader, ed. John Louis Lucaites, Celeste Michelle Condit, and Sally Caudill (New York: The Guilford Press, 1999), 147

Vytiaz, Alina. (2018). Youtube - a new era of TV?. Unpublished doctoral dissertation, Masaryk University, Ceko

Zhu, Y. (2005). Written communication across cultures: a sociocognitive perspective on MCbusiness genres. J. Benjamins Pub.

CNN Indonesia. (2020). https://www.youtube.com/watch?v=QUaa_EFQZcM diakses pada 11 Januari 2020 pukul 23.00 WIB

Kominfo.(2020).https://www.kominfo.go.id/content/detail/25932/apa-dan-bagaimana psbb/0/infografis diakses pada 13 Januari 2020 pukul $23.00 \mathrm{WIB}$ 